\title{
Wage discrimination over the business cycle
}

\author{
Jeff E Biddle ${ }^{1 *}$ and Daniel S Hamermesh ${ }^{2}$
}

\footnotetext{
* Correspondence: biddle@msu.edu Michigan State University, East Lansing MI, USA

Full list of author information is available at the end of the article
}

\begin{abstract}
Using CPS data from 1979-2009 we examine how cyclical downturns and industry-specific demand shocks affect wage differentials between white non-Hispanic men and women, Hispanics and non-Hispanic whites, and African-Americans and non-Hispanic whites. Women's relative earnings are harmed by negative shocks; the wage disadvantage of African-Americans drops with negative shocks, while the impact on Hispanics' wages is unclear. A theory of job search suggests two opposite-signed mechanisms that affect these wage differentials. It suggests greater absolute effects among job-movers, which is verified using the longitudinal component of the CPS.

Jel codes: J7, E3

Keywords: Wage discrimination; Business cycles
\end{abstract}

\section{Introduction and history}

For nearly 50 years the measurement of wage differentials between racial and ethnic groups, and between genders, has been a mainstay of empirical labor economics. Nearly all of the empirical work has implicitly been grounded in Becker's (1957) taste-based approach; and almost the entire oeuvre has either measured crosssection differentials or considered trends in these differences, which we, following the literature, refer to throughout as "discriminatory." Relative to the attention paid to cross-section differences and trends in wage effects, remarkably little attention has been paid to how these differentials vary with the extent of labor-market tightness. The issue was mentioned only in passing in the first Handbook survey (Cain, 1986) and was not even alluded to in subsequent Handbook surveys (Altonji and Blank, 1999; Fryer 2011).

A few studies from the 1970s and 1980s did attempt to measure the cyclicality of discriminatory wage differentials (Ashenfelter, 1970; Freeman, 1973; O’Neill, 1985), analyzing aggregate time series of the ratio of annual earnings of disadvantaged compared to other workers. Measured cyclical movements in ratios of earnings per hour could arise from two distinct mechanisms: changes over the cycle in the characteristics of the workers in each group (composition effects) and changes over the cycle in pure wage discrimination. The authors recognized this and pointed to both mechanisms as reasons for expecting cyclicality in measured discriminatory wage gaps. Discussions of composition effects pointed to the greater "vulnerability" of women and minorities to cycle-related job loss, but also noted the tendency for women and minorities to be employed in more stable, albeit lower-wage, industries. Both O'Neill and Freeman concluded that composition effects

(c) 2013 Biddle and Hamermesh; licensee Springer. This is an Open Access article distributed under the terms of the Creative Commons Attribution License (http://creativecommons.org/licenses/by/2.0), which permits unrestricted use, distribution, and reproduction in any medium, provided the original work is properly cited. 
led to a counter-cyclical movement in measured discriminatory wage differentials. Freeman and Ashenfelter offered reasons for suspecting that true wage discrimination would also be counter-cyclical, with the latter referring to an apparently common argument of the time that the perceived cost to employers of discriminating was higher in tight labor markets. But neither found empirical evidence of cyclical movements in pure wage discrimination in the aggregate data.

Since the mid-1990s, despite the continuing volatility of aggregate and local labor markets, including the turmoil caused by the Great Recession, almost no attention has been given to the relationship between labor market tightness and discriminatory wage differentials. Numerous studies have used the CPS and other individual level data sets to study longer-term movements in discriminatory wage differentials, but with almost no mention made of the possible cyclicality of such differentials ${ }^{1}$.

This neglect seems unfortunate for policy purposes: We know the implications and concerns for the prospects of different demographic groups' employment as aggregate demand changes: Blacks and Hispanics' employment is more volatile than that of whites, while men's employment has been more volatile than women's, especially during the Great Recession. But knowing how the relative prices of an hour of workers' time vary over the cycle across these different race/ethnicity gender groups, after accounting for other characteristics, is just as important. Total earnings, adjusted for unchanging personal characteristics that affect earnings, is a crucial input into measuring well-being and its cyclical variation. Careful measurement of cyclical changes in relative wages is thus an essential step in inferring the path of cyclical changes in the relative well-being of different groups.

In this study we provide this measurement. In the next section we document the paths of wage differentials by gender (female/male), ethnicity (Hispanic/non-Hispanic) and race (black/white), using the Current Population Survey Merged Outgoing Rotation Groups (CPS-MORG) from 1979 through 2009. This is a sufficiently long period to cover four (or five, if one considers the early 1980s recessions as distinct) aggregate cycles. Since the CPS-MORG files provide individual level data with industry and geographic identifiers, we can measure more accurately the labor market environment facing each worker; and the longitudinal component of the CPS-MORG data allows us to distinguish changes in measured wage differentials due to changes in pure wage discrimination from those due to composition effects, both observable and unobservable.

We find that the male-female wage gap is counter-cyclical, that is, the wage disadvantage faced by women grows when and where unemployment is temporarily higher. This does not appear to be due to a composition effect, but rather to changes in pure wage discrimination. The measured discriminatory gap for African-Americans, on the other hand, is pro-cyclical, but this is partly the result of composition effects. The cyclical behavior of the wage disadvantage faced by Hispanics is unclear. Section 3 sets out a search-theoretic model of discrimination to aid in interpreting the evidence. We show that a standard random search model with employer discrimination implies a cost to employers of indulging discriminatory tastes that varies pro-cyclically, thus providing a formal version of the argument cited in early work; but the model also points to other ways that discriminatory wage differentials will be affected by a changing unemployment-vacancy ratio that work in the opposite direction. One implication of this model, that economic fluctuations will change 
discriminatory wage differentials chiefly through their impact on the wage changes experienced by job-changers, is supported in the data.

\section{Data and evidence-Current Population Survey, 1979-2009}

\subsection{Basic estimates}

Throughout this section we use the Current Population Survey Merged Outgoing Rotation Groups beginning 1979, the first year for which they are available. We proxy wages by reported usual weekly earnings but adjust weekly earnings by including a quadratic in usual weekly hours among the independent variables. We divide the working population into four exhaustive and mutually exclusive groups, non-Hispanic white males, non-Hispanic white females, non-black Hispanics, and African-Americans, and create indicator variables $M$ for the last three groups ${ }^{2}$. In addition, except in the initial estimates we adjust wages by holding constant for a wide range of CPS covariates, $\mathrm{X}$, including a vector of indicators of educational attainment, a quadratic in potential experience, and indicators of marital status, metropolitan location, veteran status and private/public sector employment ${ }^{3}$. The samples are restricted to civilian wage and salary workers-the self-employed are excluded, as are members of the armed forces.

For each year we calculate the unemployment rate $U$ in each state and use that as the state-specific cyclical indicator ${ }^{4}$. We thus estimate:

$$
\mathrm{W}_{\text {ist }}=\alpha_{1} \mathrm{M}_{\mathrm{ist}}+\alpha_{2} \mathrm{U}_{\mathrm{st}}+\alpha_{3} \mathrm{M}_{\mathrm{ist}} \mathrm{U}_{\mathrm{st}}+\beta \mathrm{X}_{\mathrm{ist}}+v_{\mathrm{s}}+\tau_{\mathrm{t}}+\varepsilon_{\text {ist }},
$$

where i denotes an individual, $\mathrm{s}$ a state and $\mathrm{t}$ a year, and $\mathrm{W}$ is the logarithm of weekly earnings. The $v_{s}$ and $\tau_{t}$ are state and year fixed effects respectively. While we initially estimate (1) without either of these vectors, and then include only the year fixed effects, to save space

Table 1 Coefficient estimates describing in (usual weekly earnings) and state unemployment rates, CPS-MORG, 1979-2009, all workers*

\begin{tabular}{|c|c|c|c|c|c|c|}
\hline \multirow[b]{2}{*}{ M } & \multicolumn{2}{|c|}{$\begin{array}{c}\text { Nonhispanic Whites, } \\
\text { females relative to males }\end{array}$} & \multicolumn{2}{|c|}{$\begin{array}{l}\text { Nonblack Hispanics } \\
\text { (relative to Nonhispanic Whites) }\end{array}$} & \multicolumn{2}{|c|}{$\begin{array}{l}\text { Blacks (relative to } \\
\text { Nonhispanic Whites }\end{array}$} \\
\hline & -0.0764 & -0.0717 & -0.2086 & -0.1902 & -0.1453 & -0.1523 \\
\hline & $(0.0018)$ & $(0.0018)$ & $(0.0032)$ & $(0.0033)$ & $(0.0026)$ & $(0.0026)$ \\
\hline \multirow[t]{2}{*}{$\mathrm{M} \times$ Married } & -0.1546 & -0.1548 & & & & \\
\hline & $(0.0011)$ & $(0.0011)$ & & & & \\
\hline \multirow[t]{2}{*}{$U^{* *}$} & 0.8104 & 0.5062 & 0.3453 & -0.0580 & 0.3722 & 0.0532 \\
\hline & $(0.0220)$ & $(0.0277)$ & $(0.0180)$ & $(0.0242)$ & $(0.0178)$ & $(0.0239)$ \\
\hline \multirow[t]{2}{*}{$M \times U$} & -0.8744 & -0.9163 & 0.6360 & -0.0280 & 0.1098 & 0.3660 \\
\hline & $(0.0254)$ & $(0.0252)$ & $(0.0512)$ & $(0.0516)$ & $(0.0394)$ & (0.0395) \\
\hline \multicolumn{7}{|l|}{ Fixed effects: } \\
\hline State & & $x$ & & $x$ & & $x$ \\
\hline Year & $x$ & $x$ & $x$ & $x$ & $x$ & $x$ \\
\hline Adj. $R^{2}$ & 0.698 & 0.704 & 0.689 & 0.694 & 0.693 & 0.698 \\
\hline$N=$ & $4,343,280$ & & $4,734,522$ & & $4,829,326$ & \\
\hline $\begin{array}{l}\text { Average effect of } \\
M \text { (log points) }\end{array}$ & -0.223 & -0.221 & -0.170 & -0.192 & -0.139 & -0.130 \\
\hline
\end{tabular}

*Each equation includes a vector of indicators of educational attainment, quadratics in usual hours and potential experience, and indicators of marital status, metropolitan location, veteran status and private/public sector employment. The equations also include an inter-action of gender and marital status, and those in Columns 3-6 include a main effect of gender. Robust standard errors in parentheses below the parameter estimates here and in Tables 2, 3 and 4.

**Measured as a fraction here and in subsequent tables. 
most of the tables shown below report results from regressions that include both vectors (although Table 1 also reports results excluding the vector of state fixed effects).

We report results for three different samples. The first includes only non-Hispanic whites, with $M_{i}$ equaling one for females and the estimates of $\alpha_{1}+\alpha_{3} U$ denoting the wage differential between women and men among non-Hispanic whites. The second sample consists of non-Hispanic whites and non-black Hispanics, with $M_{i}$ equaling one for non-black Hispanic workers and $\alpha_{1}+\alpha_{3} U$ measuring the wage differential between them and non-Hispanic whites. The third consists of non-Hispanic whites and African-Americans, with $M_{i}$ equaling one for African Americans and $\alpha_{1}+\alpha_{3} U$ measuring the wage differential between non-Hispanic whites and AfricanAmericans. The coefficients on $U$ listed in the Table treat unemployment as a fraction of the labor force.

When we estimate (1) with the vector of state fixed effects we are implicitly adding a focus on temporary variations in the tightness of state labor markets to the cyclical variation in economy-wide labor market tightness. This specification accounts for the possibility that in certain states unemployment may be above or below the national average in most or all years (although Marston, 1985, suggests not). Such long-term differences are arguably related to wage differences (e.g., Hall, 1970, but going back to Smith, 1776). When we estimate (1) including the vector of year fixed effects, we are implicitly abstracting from aggregate cycles. Adding both state and year fixed effects to the regression reduces the precision in our estimates of the impact of changes in unemployment on discriminatory wage differentials, but alleviates bias caused by correlations between secular changes in the natural rate of unemployment, real wages, and the presence of women and minorities in the labor force.

Before turning to the estimates of (1), we focus on the effect of the cycle on these wage differentials absent any demographic controls, year or state fixed effects, controlling only for hours worked and a time trend. Without any controls we estimate that white women's wages relative to white men's fall by 1.2 percent with each one percentage-point increase in the unemployment rate. Non-black Hispanics' wages rise relative to non-Hispanic whites' wages by 0.9 percent in response to the same rise in unemployment, and African-Americans' wages similarly rise by 0.3 percentage points. Even without any adjustments it is clear that no single pattern characterizes cyclical changes in "discriminatory" wage differentials ${ }^{5}$.

Table 1 contains the main results of the estimated equations that include the "minority" indicators. We show only the main effect of the indicator, the main effect of the state unemployment rate, and their interactions-the parameters $\alpha_{j}$, as the estimates of the $\beta$ are standard. Consider first the results for women. With a mean state unemployment rate of 0.0601 over this period, the wage disadvantage of women, other things equal, averages about 20 percent. The interaction term remains significantly negativeas the unemployment rate increases the wage disadvantage facing women increases. This effect is about the same whether or not we include state fixed effects. Measured wage discrimination against females generally is counter-cyclical ${ }^{6}$.

Considering next the results in Columns (3) and (4) for non-black Hispanics, we see that generally their wage disadvantage is around 16 percent. The pattern of the Hispanic wage disadvantage is weakly and insignificantly counter-cyclical once we control for state fixed effects. When these are excluded the interaction term for Hispanics is 
positive and statistically significant. Because of the concentration of Hispanics in a few, high-unemployment states, excluding the vector of state indicators is incorrect.

The final two columns of Table 1 present the results for African-Americans. The wage disadvantage overall averages about 12 percent. More important, the interaction terms are positive and statistically significant whether or not we include state fixed effects ${ }^{7}$.

None of these conclusions is changed greatly if the sample is restricted in various reasonable ways. For example, excluding public-sector employees changes the coefficients on the interaction terms reported in Columns (2), (4) and (6) of Table 1 to -0.915 (s.e. $=0.025),-0.114($ s.e. $=0.055)$ and 0.341 (s.e. $=0.045)$ respectively. Adding separate trend terms for the nine Census sub-regions to the specifications in the table generates estimated interactions of $-0.912($ s.e. $=0.025),-0.056($ s.e. $=0.052)$ and 0.397 (s.e. $=0.040$ ). Finally, excluding the roughly twenty percent of observations whose reported earnings in the CPS are allocated produces estimated interactions of -0.804 (s.e. $=0.025), 0.073$ (s.e. $=0.051$ ) and 0.188 (s.e. $=0.039)^{8}$.

Another concern is that, even with state and year fixed effects, the estimates of (1) constrain the effect of minority status on earnings to be the same in all states, which is inconsistent with numerous findings (going back to Becker, 1957). Also, there may be differences in attitudes toward minorities across states that are correlated with the minorities' wage disadvantages. Accordingly, we re-estimate (1) adding state- $M$ interactions. The resulting estimates of $\alpha_{3}$ are $-0.892(\mathrm{~s} . \mathrm{e}=0.029), 0.528$ (s.e.= 0.056$)$ and 0.317 (s.e. $=0.043)$ for women, Hispanics and African-Americans respectively. As with the alternative specifications discussed above, nothing much changes for women and African-Americans. For Hispanics, on the other hand, the estimate changes drastically, no doubt because of the very uneven concentrations of Hispanics across states over much of this period. The change illustrates the difficulty of estimating this effect for Hispanics.

The impacts of a typical recession vary sharply across gender/race/ethnic groups, with the biggest effect among women. Based on the estimates in Column (2), for them an increase of 4.7 percentage-points in average unemployment (which occurred in the Great Recession) increases their wage disadvantage by over 4 percentage points; among Hispanics the effect is tiny-an increase in their wage disadvantage of slightly more than 0.1 percentage points, while among African-Americans this severe a recession reduces their wage disadvantage by about 1.7 percentage points.

Whether these effects result from economy-wide cycles or state-specific shocks can be inferred by re-estimating (1) including interactions of $M$ with indicators for each year, which eliminates economy-wide fluctuations in unemployment as a source of identification, but alleviates potential biases caused by correlations between secular changes in the natural rate of unemployment and secular changes in attitudes towards women and minorities.. The estimates of the $\alpha_{3}$ become -0.289 (s.e. $=0.036$ ), -1.777 (s.e. $=0.083$ ) and 0.292 (s.e. $=0.059)$ for women, Hispanics and African-Americans respectively. These differ substantially from those reported in Table 1. The estimate for women is in the same direction as the estimate in Table 1, and is still statistically significant, but it indicates that common aggregate cycles have larger negative impacts on the female wage disadvantage than do idiosyncratic state-specific cycles. For Hispanics, the estimates continue to suggest how dependent the inference is on the particular specification, while for African-Americans 
there is only a slight reduction in the beneficial impact of higher unemployment on the wage disadvantage.

\subsection{Extensions}

The results thus far have been based on samples covering thirty-one years. Given the documented changes in the labor markets for members of all three "minorities," perhaps the extent of cyclical variation in their wages over this period changed too. To examine this possibility we first divide the entire sample period into two parts, 197992 and 1993-2009 (each thus comprising two aggregate business cycles) and reestimate the equations.

The estimates over these two sub-periods are shown in Table 2. Among women the results in the earlier sub-period are the same as before-apparently increasing discrimination as unemployment increases; but in the later sub-period the results reverse, with apparent discrimination falling as unemployment increases. Among Hispanics the estimates are consistent with those in Table 1, and perhaps even stronger, showing that the wage disadvantage increases as unemployment increases. Among African-Americans the estimates suggest a roughly similar conclusion as those for the entire time periodthat the wage disadvantage declines when the unemployment rate rises-although the relationship in the latter sub-period is weak.

Table 2 Coefficient estimates describing in (usual weekly earnings), CPS-MORG, sub-periods 1979-1992, 1993-2009, all workers*

\begin{tabular}{|c|c|c|c|}
\hline & $\begin{array}{l}\text { Nonhispanic Whites, } \\
\text { females relative to males }\end{array}$ & $\begin{array}{l}\text { Nonblack Hispanics } \\
\text { (relative to Nonhispanic Whites) }\end{array}$ & $\begin{array}{c}\text { Blacks } \\
\text { (relative to Nonhispanic Whites) }\end{array}$ \\
\hline & & 1979-1992 & \\
\hline \multirow[t]{2}{*}{ M } & -0.1003 & -0.1788 & -0.1335 \\
\hline & $(0.0025)$ & $(0.0062)$ & $(0.0037)$ \\
\hline \multirow[t]{2}{*}{$\mathrm{M} \times$ Married } & -0.1904 & & \\
\hline & $(0.0015)$ & & \\
\hline \multirow[t]{2}{*}{ U } & 0.3094 & -0.0338 & 0.0033 \\
\hline & $(0.0358)$ & $(0.0316)$ & $(0.0312)$ \\
\hline \multirow[t]{2}{*}{$M \times U$} & -0.6225 & -0.1786 & 0.1390 \\
\hline & $(0.0312)$ & $(0.0868)$ & $(0.0492)$ \\
\hline Adj. $R^{2}$ & 0.711 & 0.705 & 0.707 \\
\hline \multirow[t]{2}{*}{ N } & $2,149,100$ & $2,284,349$ & $2,379,640$ \\
\hline & & 1993-2009 & \\
\hline \multirow[t]{2}{*}{ M } & -0.1369 & -0.1405 & -0.1320 \\
\hline & $(0.0029)$ & $(0.0041)$ & $(0.0043)$ \\
\hline \multirow[t]{2}{*}{$\mathrm{M} \times$ Married } & -0.1265 & & \\
\hline & $(0.0016)$ & & \\
\hline \multirow[t]{2}{*}{ U } & -0.3778 & -0.2695 & -0.1998 \\
\hline & $(0.0585)$ & $(0.0499)$ & $(0.0503)$ \\
\hline \multirow[t]{2}{*}{$M \times U$} & 0.2755 & -0.4342 & 0.0475 \\
\hline & $(0.0510)$ & $(0.0704)$ & $(0.0770)$ \\
\hline Adj. $R^{2}$ & 0.638 & 0.631 & 0.631 \\
\hline N & $2,194,180$ & $2,450,173$ & $2,449,686$ \\
\hline
\end{tabular}

*Same variables as in Table 1. State and year fixed effects in each equation. 
The cyclicality of wage differentials measured in the regressions reported thus far could arise from both cyclicality in pure wage discrimination and from unemploymentrelated changes in the unobservable characteristics of the sample of employed workers-a composition effect in the unobservables. Using the short longitudinal structure of the CPS-MORG we can examine the co-movement of unemployment rates and discriminatory wage differentials in a group of workers of constant unobservable composition. This analysis thus controls for possible interactions between a wide range of unobservable individual characteristics and the state-specific unemployment rate.

Table 3 presents the results of regressions in which the sample is restricted to observations that had positive earnings in both months 4 and 8 (one year apart) of their participation in the CPS and which include person fixed effects, so that state fixed effects are implicit in the estimation ${ }^{9}$. We present estimates for the entire sample period and then separately for the two sub-periods ${ }^{10}$. Essentially we difference (1) so that the dependent variable is the change in log-earnings, and the only independent variables are the change in the state unemployment rate, its interaction with $\mathrm{M}$, linear terms in experience and current and year-lagged weekly hours, and year fixed effects.

The results for women are unambiguous-for the whole sample and the two subperiods the wage disadvantage of women grows when and where unemployment is temporarily higher, just as it did in all the various alternative specifications of (1). Thus, the positive relationship between the unemployment rate and the wage disadvantage faced by

Table 3 Coefficient estimates describing $\Delta$ in (usual weekly earnings), CPS-MORG, 19802009 and sub-periods 1980-1992, 1993-2009, all workers, based on longitudinal data*

\begin{tabular}{|c|c|c|c|}
\hline & $\begin{array}{l}\text { Nonhispanic Whites, } \\
\text { females relative to males }\end{array}$ & $\begin{array}{c}\text { Nonblack Hispanics } \\
\text { (relative to Nonhispanic Whites) }\end{array}$ & $\begin{array}{c}\text { Blacks } \\
\text { (relative to Nonhispanic Whites) }\end{array}$ \\
\hline & & $1980-2009$ & \\
\hline \multirow[t]{2}{*}{$\Delta U$} & 0.1482 & -0.0573 & -0.0267 \\
\hline & $(0.0780)$ & $(0.0653)$ & $(0.0650)$ \\
\hline \multirow[t]{2}{*}{$M \times \Delta U$} & -0.3856 & -0.2855 & 0.1373 \\
\hline & $(0.0854)$ & $(0.1447)$ & $(0.1361)$ \\
\hline Adj. $R^{2}$ & 0.286 & 0.281 & 0.280 \\
\hline \multirow[t]{2}{*}{ N } & $1,375,689$ & $1,493,368$ & $1,524,422$ \\
\hline & & 1980-1992 & \\
\hline \multirow[t]{2}{*}{$\Delta U$} & 0.0196 & -0.0992 & -0.0736 \\
\hline & $(0.0850)$ & $(0.0730)$ & $(0.0719)$ \\
\hline \multirow[t]{2}{*}{$\mathrm{M} \times \Delta \mathrm{U}$} & -0.1796 & -0.5640 & 0.2733 \\
\hline & $(0.0887)$ & $(0.1967)$ & $(0.1490)$ \\
\hline Adj. $R^{2}$ & 0.351 & 0.349 & 0.347 \\
\hline \multirow[t]{2}{*}{ N } & 641,724 & 679,107 & 708,584 \\
\hline & & 1993-2009 & \\
\hline \multirow[t]{2}{*}{$\Delta U$} & 0.2837 & -0.0038 & 0.0256 \\
\hline & $(0.1349)$ & $(0.1114)$ & $(0.1122)$ \\
\hline \multirow[t]{2}{*}{$M \times \Delta U$} & -0.5620 & -0.2000 & 0.0456 \\
\hline & $(0.1372)$ & $(0.1816)$ & $(0.2051)$ \\
\hline Adj. $R^{2}$ & 0.252 & 0.248 & 0.246 \\
\hline $\mathrm{N}$ & 733,965 & 814,261 & 815,838 \\
\hline
\end{tabular}


women is the result of cyclical movements in pure wage discrimination. Table 3 even shows that the apparent reversal of sign of the relationship between unemployment and the male-female wage gap during the latter half of the sample period was due to a change in the impact of unobservable, unemployment-related composition effects on the measured gap rather than a change in the cyclicality of wage discrimination. This latter observation is consistent with Mulligan and Rubinstein's (2008) finding that the nature of selection into the female labor force changed between the 1970s and the 1990s, which may have resulted in changing selectivity over the cycle as well.

The estimates also show that the relatively weak positive relationship between unemployment and the wage disadvantage facing Hispanics in the cross-section becomes considerably stronger when composition effects arising from unobservables are removed. Hispanic workers who keep their jobs as unemployment rises implicitly have increasingly more desirable unobservable characteristics than do non-Hispanic white workers who keep their jobs. One possible but non-testable explanation for this fact is that a weaker labor market impinges particularly on the employment prospects of undocumented workers, whose English-language skills, which we cannot measure in the CPS, make their wages lower than those of observationally identical Hispanics. The positive co-movement of the relative wages of African-Americans and unemployment that we saw in Table 1 diminishes in magnitude and becomes insignificant when measured in this sample with unchanging unobservable composition.

While we have carefully accounted for labor-market-wide effects, treating states as labor markets, we have ignored the job-specific impacts of changes in demand. The question is whether, given the state's labor market, the impact of job-specific shocks mirrors that of a labor-market-wide shock. To examine this we re-specify (1) as:

$$
\begin{aligned}
\mathrm{W}_{\text {ist }}=\alpha_{1} \mathrm{M}_{\mathrm{ist}} & +\alpha_{2} \mathrm{U}_{\text {st }}+\alpha_{3} \mathrm{M}_{\text {ist }} \mathrm{U}_{\text {st }}+\alpha_{4} \Delta \mathrm{H}_{\text {it }}+\alpha_{5} \Delta \mathrm{H}_{\mathrm{it}} \mathrm{M}_{\text {ist }}+\alpha_{6} \Delta \mathrm{H}_{\mathrm{it}} \mathrm{U}_{\mathrm{st}}+ \\
& +\alpha_{7} \Delta \mathrm{H}_{\mathrm{it}} \mathrm{M}_{\text {ist }} \mathrm{U}_{\text {st }}+\beta \mathrm{X}_{\text {ist }}++v_{\mathrm{s}}+\mathrm{\tau}_{\mathrm{t}}+\varepsilon_{\text {ist }},
\end{aligned}
$$

where $\Delta \mathrm{H}_{\mathrm{it}}$ is the percentage change in total person-hours worked in the CPS industry between years $\mathrm{t}-1$ and $\mathrm{t}$.

We present estimates of the $\alpha_{j}$ in (2) in Table 4 for equations with the three specifications of the indicator $M$. Unemployment is treated as fractional, as before, as is $\Delta \mathrm{H}_{\mathrm{it}}$. The estimates are trimmed to remove industry/year observations in which the calculations from the CPS implied an absolute annual change in total person-hours of at least 50 percent. This amounts to deleting 2.3 percent of the industry-year observations, but only 0.1 percent of the individuals in the 1980-2009 samples (as the extreme fluctuations in industry person-hours are due to small sample sizes in a few industries) ${ }^{11}$.

The estimates of $\partial^{2} \mathrm{~W} / \partial \mathrm{M} \partial \mathrm{U}$ at the average $\Delta \mathrm{H}$ differ only very slightly from the estimates in Table 1 (not surprisingly, given the lack of correlation between state unemployment rates and annual changes in economy-wide industry hours worked) ${ }^{12}$. Thus accounting for industry-specific changes in employment does not alter the conclusion that the female wage disadvantage increases as unemployment rises, that the African-American wage disadvantage falls, and that conclusions about the Hispanic disadvantage are ambiguous.

To answer whether industry-specific shocks affect gender/racial/ethnic wage differentials in the same way as market-wide shocks, we focus on the estimates of $\partial^{2} \mathrm{~W} /$ $\partial \mathrm{M} \partial \Delta \mathrm{H}$ at the averages of $\mathrm{U}$, shown at the bottom of Table 4. Among women we 
Table 4 CPS-MORG, all workers 1980-2009, accounting for industry cyclicality, trimmed estimates*

\begin{tabular}{|c|c|c|c|}
\hline & $\begin{array}{c}\text { Nonhispanic Whites, } \\
\text { females relative to males }\end{array}$ & $\begin{array}{c}\text { Nonblack Hispanics } \\
\text { (relative to Nonhispanic Whites) } \\
\end{array}$ & $\begin{array}{c}\text { Blacks } \\
\text { (relative to Nonhispanic Whites) }\end{array}$ \\
\hline \multirow[t]{2}{*}{$\bar{M}$} & -0.0700 & -0.1980 & \\
\hline & $(0.0018)$ & $(0.0033)$ & $(0.0027)$ \\
\hline \multirow[t]{2}{*}{$\mathrm{M} \times$ Married } & -0.1507 & & \\
\hline & $(0.0011)$ & & \\
\hline \multirow[t]{2}{*}{$M \times U$} & -0.9221 & 0.0995 & 0.3869 \\
\hline & $(0.0255)$ & $(0.0524)$ & $(0.0399)$ \\
\hline \multirow[t]{2}{*}{$\Delta \mathrm{H}$} & 0.0533 & 0.0796 & 0.0694 \\
\hline & $(0.0120)$ & $(0.0096)$ & $(0.0096)$ \\
\hline \multirow[t]{2}{*}{$\Delta H^{*} U$} & -2.022 & -2.306 & -2.215 \\
\hline & $(0.159)$ & $(0.127)$ & $(0.127)$ \\
\hline \multirow[t]{2}{*}{$\Delta H^{*} \mathrm{M}$} & 0.0336 & 0.4534 & -0.0650 \\
\hline & $(0.0181)$ & $(0.0367)$ & $(0.0288)$ \\
\hline \multirow[t]{2}{*}{$\Delta \mathrm{H}^{*} \mathrm{M}^{*} \mathrm{U}$} & 0.523 & -3.695 & 1.077 \\
\hline & $(0.248)$ & $(0.536)$ & $(0.389)$ \\
\hline Adj. $R^{2}$ & 0.700 & 0.689 & 0.693 \\
\hline \multirow[t]{2}{*}{$\partial^{2} \mathrm{~W} / \partial \mathrm{M} \partial \mathrm{U}$} & -0.9139 & 0.0443 & 0.4036 \\
\hline & $(0.0255)$ & $(0.0532)$ & $(0.0399)$ \\
\hline \multirow{2}{*}{$\begin{array}{l}\partial^{2} W / \\
\partial M \partial \Delta H\end{array}$} & 0.0655 & 0.2279 & 0.0008 \\
\hline & $(0.0062)$ & $(0.0103)$ & $(0.0095)$ \\
\hline
\end{tabular}

*Includes the state and year fixed effects and the same variables as in Table 1. Trimmed to exclude observations with an absolute annual change in industry employment $\geq 50$ percent.

observe the same negative effect on wage differentials of declines in industry demand that we observed for cyclical labor-market rises in unemployment in Table $1-$ as $\Delta \mathrm{H}$ is more negative, women's wages fall relative to men's. Among Hispanics too the generally negative impacts of rising unemployment shown above are mirrored by the negative effects on their relative wages of negative industry demand shocks. Only among AfricanAmericans is there no impact of industry demand shocks.

A fair conclusion is that for women the effects of industry-specific shocks are in the same directions as those of cyclical, market-wide shocks-in both cases increasing slack increases women's wage disadvantage. The impact of changes in industry demand is not so large, however: Even a decline in average industry employment equaling the difference between the smallest (most negative) and the largest in the sample period would increase white women's wage disadvantage by 1.8 percent points-less than half of the increase occurring in a deep recession. The effect of a rise in industry demand is larger among Hispanics and, as with women, suggests a small increasing disadvantage as demand slackens.

\section{Modeling discrimination over the cycle}

The previous sections have presented compelling evidence that discriminatory wage gaps are related to labor market tightness, at least for women and African-Americans, a relationship that shows up even in analyses of co-movements of wage and 
unemployment over a year in samples of unchanging composition. The intellectual problem, however, is that the direction of the effects differs among "minority" groups. In this section we outline an equilibrium search model that provides insights into why pure wage discrimination might be related to labor market tightness, a model that builds on the work of Black (1995) and Rosén (2003), and why this relationship might differ among groups. It contains two types of workers, one of which is subject to employer discrimination in the labor market. The model explores the intuition that the rising ratio of job seekers to vacancies during a recession might give employers more scope to indulge discriminatory tastes, while bringing to light other ways that cyclical fluctuations might affect discriminatory wage differentials. We present enough of the model to make clear the key mechanisms.

There are two types of worker, type A and type B. Type A workers are favored and account for a fraction $\lambda$ of job seekers. Workers search randomly across vacancies offered by employers. Each potential vacancy is associated with a value of the discrimination coefficient $\mathrm{c}$, which is distributed across vacancies over a range from zero to $c_{\max }$. A vacancy's discrimination coefficient manifests itself as a tax on the employer who hires a type B worker into the vacancy, but it may influence the wage paid to a type A worker hired into that vacancy.

Equations (3) and (4) express the value to a worker of type i of being unemployed $\left(\mathrm{U}_{\mathrm{i}}\right)$ versus being employed in a position with discrimination coefficient $\mathrm{c}\left(\mathrm{W}_{\mathrm{i}}(\mathrm{c})\right)$.

$$
\begin{aligned}
& \mathrm{rU}_{\mathrm{i}}=\theta \mathrm{z}_{\mathrm{i}}\left[\mathrm{E}\left(\mathrm{W}_{\mathrm{i}}(\mathrm{c})\right)-\mathrm{U}_{\mathrm{i}}\right], \mathrm{i}=\mathrm{A}, \mathrm{B} \\
& \mathrm{rW}_{\mathrm{i}}(\mathrm{c})=\mathrm{W}_{\mathrm{i}}(\mathrm{c})+\mathrm{s}\left[\mathrm{U}_{\mathrm{i}}-\mathrm{W}_{\mathrm{i}}(\mathrm{c})\right]
\end{aligned}
$$

In (3) $\mathrm{r}$ is the discount rate, $\theta$ is the rate at which workers receive job offers, $\mathrm{z}_{\mathrm{i}}$ is the probability that the employer will be willing to hire the worker of type $\mathrm{i}$, and $\mathrm{E}$ $\left(\mathrm{W}_{\mathrm{i}}(\mathrm{c})\right)$ is the expected value, for worker type $\mathrm{i}$, of being employed, where the expectation is taken over the distribution of $\mathrm{c}$. In (4) $\mathrm{s}$ is an exogenous separation rate, and $\mathrm{W}_{\mathrm{i}}(\mathrm{c})$ the wage earned by a type $\mathrm{i}$ worker at a job with a discrimination coefficient of $\mathrm{c}$.

Equations (5) and (6) give the value to the employer of a vacancy and a filled job as functions of the job's discrimination coefficient, c.

$$
\begin{aligned}
& \mathrm{rV}(\mathrm{c})=-\mathrm{k}+\phi \mathrm{y}(\mathrm{c})\left[\mathrm{E}\left(\mathrm{J}_{\mathrm{i}}(\mathrm{c})-\mathrm{V}(\mathrm{c})\right]\right. \\
& \mathrm{rJ}_{\mathrm{i}}(\mathrm{c})=\mathrm{x}-\mathrm{W}_{\mathrm{i}}(\mathrm{c})-\mathrm{c}_{\mathrm{i}}+\mathrm{s}\left[\mathrm{rV}(\mathrm{c})-\mathrm{J}_{\mathrm{i}}(\mathrm{c})\right], \mathrm{i}=\mathrm{A}, \mathrm{B}
\end{aligned}
$$

In (5) $\mathrm{k}$ is the cost of keeping a vacancy open for a period, $\phi$ is the rate at which workers arrive at employers, and $y(c)$ is the probability that the randomly arriving worker will be acceptable to the employer, which depends on the vacancy's c value. The expectation in (5) is taken over the distribution of worker types. In (6) $\mathrm{x}$ is the value of a worker's product, assumed the same for all workers in all jobs, and $c_{i}$ is equal to zero if a type A worker is hired, and equal to the vacancy's discrimination coefficient if a type B worker is hired.

Because it costs to keep a vacancy open, and there is a foregone surplus from a filled job, the employer offering a vacancy with a non-zero $c$ faces a tradeoff. Hiring a type B worker has a psychic cost, c, which for some vacancies will be greater than 
the equilibrium wage discount for type B workers; but turning the worker away and waiting for a type A worker to apply generates a cost in terms of $\mathrm{k}$ and forgone $\mathrm{x}$ that is proportional to the waiting time.

Following common practice, we assume that, when a worker meets an employer in the search process, the wage is determined by a Nash bargaining process, which gives the worker a share $\beta$ of the surplus. The potential surplus for an i worker and a $c$ vacancy is $\left(\mathrm{W}_{\mathrm{i}}(\mathrm{c})-\mathrm{U}_{\mathrm{i}}\right)+\left(\mathrm{J}_{\mathrm{i}}(\mathrm{c})-\mathrm{V}(\mathrm{c})\right)$. Replacing $\mathrm{W}_{\mathrm{i}}(\mathrm{c})$ and $\mathrm{J}_{\mathrm{i}}(\mathrm{c})$ in this expression with (4) and (6) yields a wage equation for a type-i worker in a c vacancy:

$$
\mathrm{W}_{\mathrm{i}}(\mathrm{c})=\beta\left(\mathrm{x}-\mathrm{c}_{\mathrm{i}}-\mathrm{rV}(\mathrm{c})\right)+(1-\beta) \mathrm{rU}_{\mathrm{i}}
$$

Equations (5), (6), (7) can be used to derive two possible values for a c-vacancy. Let $\mathrm{V}^{\mathrm{AB}}$ represent the value of the vacancy if the employer is willing to fill it with either type of worker, and $\mathrm{V}^{\mathrm{A}}$ stand for the value of the vacancy if the employer hires only A type workers. Then:

$$
\begin{aligned}
& \mathrm{rV}^{\mathrm{AB}}(\mathrm{c})=\left\{-\mathrm{k}(\mathrm{r}+\mathrm{s})+(1-\beta) \phi\left[\mathrm{x}-(1-\lambda) \mathrm{c}-\lambda \mathrm{rU}_{\mathrm{A}}-(1-\lambda) \mathrm{rU}_{\mathrm{B}}\right]\right\} /(\mathrm{r}+\mathrm{s}+(1-\beta) \phi) \\
& \mathrm{rV}^{\mathrm{A}}(\mathrm{c})=\left\{-\mathrm{k}(\mathrm{r}+\mathrm{s})+(1-\beta) \phi \lambda\left[\mathrm{x}-\mathrm{rU}_{\mathrm{A}}\right]\right\} /(\mathrm{r}+\mathrm{s}+(1-\beta) \phi \lambda) .
\end{aligned}
$$

Whether a vacancy is segregated or integrated depends on which of these values is higher, and that depends on the value of c. Setting (8a) equal to (8b) gives a cutoff value $\mathrm{c}^{*}$, such that vacancies for which $\mathrm{c}>\mathrm{C}^{*}$ will be filled only with A workers:

$$
\mathrm{c} *=\left\{\left[(\mathrm{r}+\mathrm{s})(\mathrm{k}+\mathrm{x})+(1-\beta) \phi \lambda \mathrm{rU}_{\mathrm{A}}\right] /[\mathrm{r}+\mathrm{s}+(1-\beta) \phi \lambda]\right\}-\mathrm{rU}_{\mathrm{B}}
$$

A higher $\mathrm{c}^{*}$ means less discrimination. A higher cost of waiting (k) or a higher value of production $(\mathrm{x}$ ) leads to less discrimination, since the cost of discriminating is waiting for the next worker to come along if a B worker is denied the job.

Let $\mathrm{H}\left(\mathrm{c}^{*}\right)$ be the probability that $\mathrm{c}<\mathrm{c}^{*}$, so that $\mathrm{z}_{\mathrm{B}}$, the probability that a vacancy found by a type $B$ worker will be filled by him, is $H\left(c^{*}\right)$, while $z_{A}=1$. Then (3) and (4) and the wage equation (7) yield expressions for the value of search for each type of worker:

$$
\begin{aligned}
& \mathrm{rU}_{\mathrm{A}}=[\theta \beta \mathrm{E}(\mathrm{x}-\mathrm{rV}(\mathrm{c}))] /(\mathrm{r}+\mathrm{s}+\theta \beta) \\
& \mathrm{rU}_{\mathrm{B}}=[\theta \beta \mathrm{E}(\mathrm{x}-\mathrm{c}-\mathrm{rV}(\mathrm{c}) \mid \mathrm{c}<\mathrm{c} *) \mathrm{H}(\mathrm{c} *)] /(\mathrm{r}+\mathrm{s}+\theta \beta \mathrm{H}(\mathrm{c} *))
\end{aligned}
$$

where the expectations are over the distribution of c. These equations can be used to show that $U_{A}>U_{B}$, which, given the wage equation (7), implies that in equilibrium the $\mathrm{B}$ worker receives a lower wage than the $\mathrm{A}$ worker at any employer willing to hire both types ${ }^{13}$. Also, as $\mathrm{V}^{\mathrm{AB}}$ is declining in $\mathrm{c}$, wages for both $\mathrm{A}$ and $\mathrm{B}$ workers fall as $\mathrm{C}$ increases up to $\mathrm{C}^{*}$, at which point there is no wage for $\mathrm{B}$ workers and the A wage remains constant.

The arrival rate of workers $\phi$, which is one factor determining the cost to employers of discrimination, depends on the processes governing the number of searching workers and the number of vacancies offered. Letting the total number of workers equal 1, a fraction $\alpha$ of whom are type $A$, and letting the number unemployed for type $A$ and type $B$ workers be $u_{A}$ and $u_{B}$, the change over time in the number unemployed can be written as $d u_{A}=s\left(\alpha-u_{A}\right)-\theta u_{A}$ and $d u_{B}=s$ 
$\left((1-\alpha)-\mathrm{u}_{\mathrm{B}}\right)-\theta \mathrm{H}\left(\mathrm{c}^{*}\right) \mathrm{u}_{\mathrm{B}}$. In a steady state unemployment is constant, so that the steady-state rates of unemployment are given by:

$$
\begin{aligned}
& \mathrm{u}_{\mathrm{A}}=\alpha \mathrm{s} /(\mathrm{s}+\theta) \\
& \mathrm{u}_{\mathrm{B}}=(1-\alpha) \mathrm{s} /(\mathrm{s}+\theta \mathrm{H}(\mathrm{c} *)) .
\end{aligned}
$$

Group-specific unemployment rates can be found by dividing (11a) and (11b) by $\alpha$ and $(1-\alpha)$, respectively, leading to the unsurprising result that the unemployment rate for B type workers will always be higher than the unemployment rate for A type workers. Also, $\lambda$, the share of unemployed workers who are Type A, will always be lower than $\alpha$, the share of type A workers in the economy.

To endogenize the number of vacancies, assume that there are $M$ potential vacancies that will become actual vacancies if their value is greater than zero. In order to have an equilibrium in which discriminators can survive long-run entry, we follow Black (1995) by assuming differences in entrepreneurial ability that are attached to potential employers. Entrepreneurial ability is represented by a fixed cost that is incurred if a vacancy is opened (and persists whether it is filled or not). We represent this cost by the parameter $\varepsilon$, assumed to be distributed uniformly across vacancies on the interval 0 to $\mathrm{R}_{\varepsilon}$, independent of the discrimination coefficient $\mathrm{c}$, which is also assumed to be distributed uniformly across potential vacancies. The fixed cost parameter appears as a term subtracted from the value equations (8a) and (8b).

Potential vacancies will become actual vacancies if:

$$
\begin{aligned}
& \varepsilon_{j}<\mathrm{rV}^{\mathrm{AB}}\left(\mathrm{c}_{\mathrm{j}}, \mathrm{c} *\right) \text { if } \mathrm{c}_{\mathrm{j}}<\mathrm{c} * \\
& \varepsilon_{\mathrm{j}}<\mathrm{rV}^{\mathrm{A}}(\mathrm{c} *) \text { if } \mathrm{c}_{\mathrm{j}}>\mathrm{c} *,
\end{aligned}
$$

where $j$ indexes vacancies, each of which has an $\varepsilon$ value and a c value. The value of vacancy equations are function of $c^{*}$ because the value of search $U_{i}$, which affects the value of a vacancy, is a function of $c^{*}$. The value of a vacancy is a direct function of $c$ only for employers who integrate. This means that in equilibrium, the number of vacancies will be:

$$
\mathrm{v}=\left\{\mathrm{M} /\left(\mathrm{c}_{\max } \mathrm{R}_{\varepsilon}\right)\right\}\left\{\int_{0}^{\mathrm{c} *} \mathrm{rV}^{\mathrm{AB}}(\mathrm{c}, \mathrm{c} *) \mathrm{dc}+\left(\mathrm{c}_{\max }-\mathrm{c} *\right) \mathrm{rV}^{\mathrm{A}}(\mathrm{c})\right\} .
$$

With equations for the number of vacancies and the number of unemployed workers we can characterize the arrival rates $\theta$ and $\phi$. As is common in the literature, we assume a matching function $m\left(u_{A}+u_{B}, v\right)$ that describes the number of meetings between searching workers and vacancies that will occur in a period. Adding the conventional assumption that the matching function exhibits constant returns to scale allows the rate at which a searching worker meets a vacancy to be written as:

$$
\theta=\mathrm{m}\left(\mathrm{u}_{\mathrm{A}}+\mathrm{u}_{\mathrm{B}}, \mathrm{v}\right) /\left(\mathrm{u}_{\mathrm{A}}+\mathrm{u}_{\mathrm{B}}\right)=\mathrm{m}\left(1, \mathrm{v} /\left(\mathrm{u}_{\mathrm{A}}+\mathrm{u}_{\mathrm{B}}\right)\right)
$$

while the rate at which employers see workers showing up at vacancies is:

$$
\phi=\mathrm{m}\left(\mathrm{u}_{\mathrm{A}}+\mathrm{u}_{\mathrm{B}}, \mathrm{v}\right) / \mathrm{v}=\mathrm{m}\left(\left(\mathrm{u}_{\mathrm{A}}+\mathrm{u}_{\mathrm{B}}\right) / \mathrm{v}, 1\right)
$$

In the context of this model, we represent macroeconomic fluctuations as changes in $x$, the value to the firm of a workers' output. It is possible to differentiate the 
equilibrium value of the wage gap with respect to changes in $\mathrm{x}$, but this leads to a complex and non-transparent expression with an ambiguous sign. The model can, however, be used to think through the step-by-step impact of a recession on employers, workers, and market-level variables, thus providing some insight into the sources of this ambiguity and their possible correspondence to real world phenomena.

As discussed above, one cost to discriminating is the opportunity cost of the longer expected wait until an acceptable worker arrives, and this cost falls with a fall in the value of output. Employers who might not discriminate when the value of output is high will do so when it is low. Thus the model captures the idea that discrimination will be more costly in a tighter labor market. A greater proportion of discriminating employers in the labor market lowers the bargaining power of type B workers relative to type A workers, increasing the wage gap.

Another immediate impact of a drop in $\mathrm{x}$, however, serves to increase the bargaining power of type B workers. Other things equal, the fall in the value of workers' product lowers the perceived value of both filled jobs and vacancies, causing some vacancies and jobs to be eliminated. But the model suggests that, under a wide range of circumstances, jobs and vacancies that are closed to type B workers are more likely to disappear. The existence of differing entrepreneurial ability means that there are marginal positions at every level of $\mathrm{c}$, and these are the positions (filled or vacant) that disappear when a recession lowers $\mathrm{x}$. There are, however, more infra-marginal positions at lower values of $\mathrm{c}$. Therefore it will typically be the case that when $\mathrm{x}$ falls the proportion of positions that disappears is greater at higher values of $\mathrm{c}$. This tends to lower the share of type-A only vacancies, raising the value of search for type B workers, and thus raising their bargaining power and wages relative to those of A workers.

Figure 1 depicts the nature of the equilibrium and illustrates these two initial and countervailing effects of a recession. On the axes are $\varepsilon$ and c, so that potential vacancies are distributed uniformly over the quadrant. The line labeled $V(c)=0$ shows the dividing line between combinations of $\mathrm{c}$ and $\varepsilon$ for which vacancies have positive utility (below the line) and those for which they have negative utility. Positive utility vacancies with $\mathrm{c}>\mathrm{C}^{*}$ hire only majority (A) workers; because $\mathrm{V}\left(\mathrm{c}\right.$ ) declines in $\mathrm{c}$ up to $\mathrm{c}^{*}$, some $\mathrm{AB}$ (integrated) vacancies yield a higher surplus than any segregated vacancy. The first

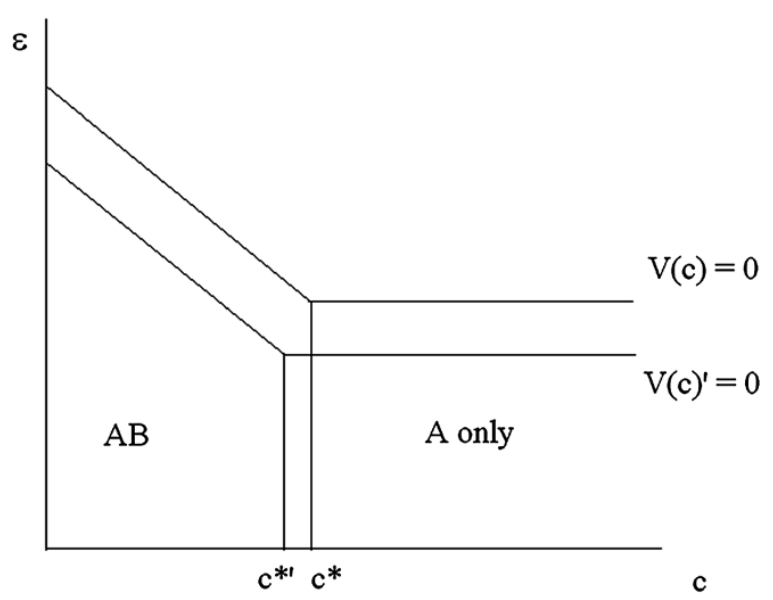

Figure 1 Job openings and employers' tastes for discrimination. 
impact of a recession is to lower the value of a vacancy (the shift from $V(c)$ to $V(c)$ ' in the figure) in a way that lowers the level of $c^{*}$, decreasing the share of positions potentially open to type B workers, and increasing the wage gap. However, as the figure also shows, the proportion of segregated positions that disappears is larger than the proportion of integrated positions that disappears, as a consequence of the fact that there are more infra-marginal positions at values of $\mathrm{c}$ below $\mathrm{c}^{*}$.

As positions disappear, the rate at which workers arrive at employers rises, but the rate at which workers find new vacancies drops. As noted above, the higher arrival rate of workers at vacancies lowers the cost of discriminating, because a faster arrival of the next worker means less foregone output when a type B worker is turned away ${ }^{14}$. This lowers the cutoff value of $\mathrm{C}^{*}$, which in turn lowers the value of search for type $B$ workers relative to type A workers. A similar effect results from disproportionately more type A than type B workers losing jobs, raising the share of type A workers among the searchers and lowering the expected waiting time for the next type A applicant for firms who turn away type B workers. The lower arrival rate of job offers to workers lowers the value of search for both type A and type B workers, which lowers the wage of both types; but it lowers the value of search more for type A workers. This decreases the wage gap, but is a rather subtle, non-intuitive effect, as are the impacts of the many of the subsequent equilibrating reactions of the model's variables to the initial events set in motion by a fall in $\mathrm{x}$.

Although our model leaves open the question of whether discriminatory wage differentials are pro-cyclical or counter-cyclical, it does identify several distinct mechanisms through which business-cycle fluctuations could plausibly alter discriminatory wage differentials. These include cycle-induced changes in the costs and benefits of discrimination in hiring and changes in the mix of discriminators vs. non-discriminators in the labor market caused by entry or exit of firms. In addition, our argument suggests that changes in discriminatory wage differentials accompanying aggregate fluctuations will arise from the impact of these fluctuations on changes in the relative wages of advantaged vs. disadvantaged workers who leave one job and search for another, not on their impact on wages of workers continuing in the same job. Indeed, the model predicts that we will observe these effects for job-changers only, since there is no mechanism in the model through which wages change for workers who do not change employers.

\section{Job-movers vs. job-stayers}

There is substantial evidence (e.g., Devereux and Hart, 2006) that wages generally are more procyclical among job-movers than job-stayers. The question suggested by Section 4 is whether gender/ethnic/racial wage differentials are more cyclical (either pro- or countercyclical) among job-movers than among job-stayers. The short longitudinal structure of the CPS allows us to answer this question, thus providing a test of the model's implication that changes in unemployment affect wage gaps through their impact on the wage changes experienced by job-changers.

The CPS does not identify employers, so we assume that workers who list the same small industry of employment in interviews in Years $t-1$ and $t$ are job-stayers, while those who list different industries are job-movers. Given evidence of substantial reporting error in the self-classification of industry affiliation (Freeman, 1984), our test 
will thus underestimate the differences in effects between job-stayers and job-movers, since some job-stayers will mistakenly be classified as job-movers. Finally, with losses of perhaps $1 / 3$ of the CPS observations due to an inability to match across the pair of years, and other observations dropped because individuals enter or leave employment, the sample sizes here are smaller than those used in the cross-section analyses in Section 3 (but, of course, the same as in the analyses reflected in Table 3).

To save space, in Table 5 we present only estimates of the interaction terms $\partial^{2} \Delta \mathrm{W} /$ $\partial \mathrm{M} \partial \mathrm{U}$ and their standard errors from the equations for job-stayers and -movers, along with what is essentially the triple difference $\left[\partial^{2} \Delta \mathrm{W} / \partial \mathrm{M} \partial \mathrm{U}\right]_{\text {MOVER }}-\left[\partial^{2} \Delta \mathrm{W} /\right.$ $\partial \mathrm{M} \partial \mathrm{U}]_{\text {STAYER }}$. The evidence in the table supports the model's predictions. The relationship between labor-market tightness and the wage disadvantage facing women is significantly greater in the sample of job-movers than in the sample of job-stayers. Remembering from Table 1 that the wage disadvantage of African-Americans drops significantly when unemployment rises, the results here suggest that this gain is due to the behavior of wage changes among job-movers: Among African-Americans the wage disadvantage becomes smaller among job-movers as unemployment rises, but hardly varies among job-stayers. Among Hispanics the negative impact of the cycle is, however, equally pronounced among job-movers and -stayers, again showing the ambiguities in the estimates of the cyclical variation in this discriminatory differential.

Only for women compared to men are the differences between job-movers and job-stayers statistically significant. The difference for blacks is large but only statistically significant at a very low level, while the results for Hispanics at least do not contradict our interpretation of our theory. Remembering, however, that our method of distinguishing job-movers and stayers necessarily blurs the distinction between them, these results do seem somewhat convincing. They suggest that it is through wage-setting as new employment relations are entered into that the changing market effects of discrimination become felt. Short-run increases in unemployment have less effect on wage differentials within continuing jobs.

\section{Conclusion and implications}

We have documented a relationship between measured discriminatory wage differentials and labor market tightness, as indicated by either state unemployment rates or

Table 5 Coefficient estimates describing $\Delta$ in (usual weekly earnings), CPS-MORG, 1980-2009, distinguishing job-movers from job-stayers*

\begin{tabular}{|c|c|c|c|}
\hline & $\begin{array}{c}\text { Nonhispanic whites, } \\
\text { females relative to males }\end{array}$ & $\begin{array}{c}\text { Nonblack Hispanics } \\
\text { (relative to Nonhispanic Whites) }\end{array}$ & $\begin{array}{c}\text { Blacks } \\
\text { (relative to } \\
\text { Nonhispanic Whites) }\end{array}$ \\
\hline \multicolumn{4}{|l|}{$\begin{array}{l}\partial^{2} \Delta \mathrm{W} / \partial \mathrm{M} \partial \mathrm{U} \\
\text { (std. error) }\end{array}$} \\
\hline \multirow[t]{2}{*}{ Movers } & -0.7519 & -0.2714 & 0.2796 \\
\hline & $(0.1629)$ & $(0.2444)$ & $(0.2379)$ \\
\hline \multirow[t]{2}{*}{ Stayers } & -0.0741 & -0.3087 & 0.0374 \\
\hline & $(0.0904)$ & $(0.1675)$ & $(0.1561)$ \\
\hline \multirow[t]{2}{*}{ Movers-Stayers } & -0.6778 & 0.0373 & 0.2422 \\
\hline & $(0.1147)$ & $(0.2029)$ & $(0.1940)$ \\
\hline
\end{tabular}

*Same variables as in Table 3. 
industry-based measures of shifts in labor demand. We use the longitudinal component of the CPS to explore the extent to which this relationship is due to the changing composition of the labor force as the unemployment rate fluctuates vs. changes in pure wage discrimination. The evidence that a tighter labor market leads to a smaller discriminatory wage gap is strongest and most robust when comparing male and female wages, and is observed in samples of unchanging composition. We also find that the measured AfricanAmerican-white wage gap increases when the labor market tightens, but this appears to be due mainly to composition effects. The evidence on pure wage discrimination against Hispanics is ambiguous, varying depending on the sample and methods chosen ${ }^{15}$.

In a search model changes in discriminatory wage differences must come through the wage changes experienced by workers who change jobs, as it includes no mechanism through which employers alter the wages paid to continuing employees. We do find that the relationship between changes in the unemployment rate and changes in discriminatory wage differentials is stronger in samples of workers who did change jobs than in samples of job-stayers. "Discriminatory" wage disadvantages, rising with unemployment among women and falling among African-Americans, are observed disproportionally in the wage changes experienced by job-movers.

A next step in re-opening this long-neglected area of study might be to use more detailed sets of data to infer the differential roles of the mechanisms that generate cyclical changes in pure wage discrimination in our model and infer why the net effects differ among the groups we have studied. One mechanism that leads discriminatory wage gaps to vary over the cycle is the disproportionate exit of discriminators during a recession, which tends to narrow such wage gaps by raising the bargaining power of the disadvantaged group. This effect is stronger the larger the proportion of non-discriminating employers. While there is, however, ample evidence that Americans' attitudes toward employment discrimination policies differ according to the group being protected (Strolovich 1998), it is not clear that these differences are evidence of similar differences in the willingness of employers to discriminate against racial minorities vs. women.

One could also generate differences across groups in the size of the impact of "disproportionate exit" by relaxing the model's assumption of a zero correlation between employers' discriminatory attitudes and "entrepreneurial ability" (which can be seen as a stand-in for the presence of quasi-rents). The more negative this correlation, the more the bargaining power of the disadvantaged group will rise during recessions, and differences across groups in this correlation would lead to differences in the cyclical behavior of their wage gaps. Suppose, for example, that firm size is positively correlated with the presence of quasi-rents. Social scientists from various disciplines have claimed that the more formal and rule-driven hiring processes of larger firms should lead to less discrimination in hiring, but the various arguments both for and against this claim often refer specifically to the case of gender or race discrimination, and the empirical evidence is mixed (see, e.g., Kay and Gorman (2012), Baron et al. (2007)). Further research on how firm size affects discrimination and whether the effect differs across disadvantaged groups might also shed light on differences across group in the cyclicality of wage discrimination.

Perhaps the most important policy implication of this work stems from our result on the cyclical variation in the female-male wage gap. This finding suggests that relative wage variation is in the opposite direction from the well-known lesser cyclicality of 
women's than of men's employment probability. It also suggests that gender cyclical variations in the sources of economic well-being are less pronounced than one might infer from readily available data on variations in employment.

A similar conclusion can be drawn about differences between African-Americans and non-Hispanic whites (although the gross effects are in the opposite directions from those characterizing women and men, and much of the wage effect results from cyclical changes in labor-force composition). Finally, and perhaps more disturbingly, while the results on Hispanics are quite mixed, they indicate that the adjusted difference in Hispanic- and non-Hispanic-white wages does not diminish in recessions. Coupled with the well-known greater cyclicality of Hispanics' employment probabilities, this result suggests that cyclical downturns may create an especially heavy burden on that group.

\section{Endnotes}

${ }^{1}$ See, e.g., Blau and Kahn (2006), or Mulligan and Rubinstein (2008). Blanchflower and Oswald (1995) did relate wages to unemployment rates for separate demographic groups without comparing cyclical responses. Kuhn and Shen (2013) is a rare exception to this generalization, although in a very specific context; and Dustmann et al. (2010) did examine the cyclicality of immigrant-native wage differentials.

${ }^{2}$ Even for the years 2003-2009, when the CPS offered a large variety of racial characteristics, we code as African-American only those who listed that as their sole racial identification. For those years this means excluding only 3 percent of those who list themselves as partly or entirely African-American.

${ }^{3}$ We have not included a union indicator, since data on union coverage or membership are only available from 1982 on. To include it we would have had to drop three years of data, and would have lost one of the four aggregate cycles from this 31-year period.

${ }^{4} \mathrm{We}$ use the same underlying data, the ORG, to calculate state unemployment rates. Using these data may lead to slight (given the size of the ORG samples) extra measurement error compared to using the entire CPS. In any event, to the extent these errors exist, they merely mean that we under-estimate the absolute values of the impacts of interest.

${ }^{5}$ The estimates are based throughout on equations with observations weighted by the CPS sampling weights.

${ }^{6}$ None of the conclusions in this sub-section changes qualitatively if we substitute the logarithm of the state unemployment rate for the actual rate. The conclusion here is opposite that in Park and Shin (2005), which used a very short time period, a much smaller sample, and defined $U$ as aggregate rather than state-specific unemployment.

${ }^{7}$ Estimating these equations without state or year fixed effects, and substituting a trend term for the latter, yields estimates of the interaction terms of -0.896 (s.e. $=0.003$ ), 0.523 (s.e. $=0.051$ ) and 0.058 (s.e. $=0.040$ ) for the female, Hispanic and black equations.

${ }^{8}$ The results are also nearly identical if all four groups-white non-Hispanic males and females, non-black Hispanics, and African-Americans-are included in one regression, so that the control variables are constrained to have the same impacts for every worker.

${ }^{9}$ This arises because the CPS interviews individuals in particular households, not in particular families, so that house-movers fall out of the longitudinal sample. 
${ }^{10}$ Elsby et al. (2010) used the longitudinal component of the CPS to analyze a related question, how flows into and out of unemployment vary over the business cycle, without focusing on gender/race/ethnic differences in these responses.

${ }^{11}$ We spliced the series using the overlapping industry definitions in the 2002 CPS.

${ }^{12}$ This lack of correlation also means that the estimates of the interaction $\Delta \mathrm{H}_{\mathrm{it}} \mathrm{M}_{\mathrm{ist}}$ in a re-specified equation that excludes terms in $\mathrm{U}$ are almost identical to those presented in Table 4.

${ }^{13}$ As in Black (1995) and Rosén (2003), the value of search (U) is lower in equilibrium among type B workers, because they have a longer expected search time before finding a vacancy that they can fill. This weakens their bargaining position when they do find an employer, so they end up with a lower wage.

${ }^{14}$ Note that if the firm has market power (i.e., faces a downward-sloping demand curve), this cost of discriminating will be lower, other things equal. This analogous to Becker's (1957) argument that lessened product-market competition will generate greater measured discrimination, a view that has been generally supported by empirical results (e.g., Ashenfelter and Hannan, 1986).

${ }^{15}$ The filing of discrimination complaints with the Equal Employment Opportunity Commission is countercyclical for all groups, although perhaps because many of the complaints deal with terminations, which are obviously counteryclical. In a regression describing total annual filings from 1997 through 2011 and including a trend term, the total rose by about 4 percent for each 1 percentage-point increase in the aggregate unemployment rate. Similar responses exist for regressions estimated separately for claims based on sex, national origin or race, despite our evidence that wage effects by race decrease as unemployment increases. (Based on data available at http://eeoc.gov/eeoc/statistics/enforcement/charges.cfm).

Competing interests

IZA Journal of Labor Policy is committed to the IZA Guiding Principles of Research Integrity. The authors declare that they have observed these principles, and that they have no competing interests.

\section{Acknowledgement}

We thank Karen Mulligan for her excellent research assistance, and Steve Trejo, participants at several institutes and universities, the editor and two referees for their helpful comments.

Responsible editor: David Neumark.

\section{Author details \\ ${ }^{1}$ Michigan State University, East Lansing MI, USA. ${ }^{2}$ University of Texas at Austin, Royal Holloway University of London, IZA and NBER, Austin, TX, USA.}

Received: 12 April 2013 Accepted: 17 June 2013

Published: 1 July 2013

\section{References}

Altonji J, Blank R (1999) Race and gender in the labor market. In: Ashenfelter O, Card D (eds) Handbook of labor economics, volume 3C. Elsevier, Amsterdam

Ashenfelter O (1970) Changes in labor market discrimination over time. J Hum Resour 5:403-430

Ashenfelter O, Hannan T (1986) Sex discrimination and product market competition. Q J Econ 101:149-174

Baron JN, Hannan MT, Hsu G, Koçak Ö (2007) In the company of women: gender inequality and the logic of bureaucracy in start-up firms. Work Occupation 34:35-66

Becker G (1957) The economics of discrimination. University of Chicago Press, Chicago

Black D (1995) Discrimination in an equilibrium search model. J Labor Econ 13:309-333

Blanchflower D, Oswald A (1995) The wage curve. MIT Press, Cambridge, MA

Blau F, Lawrence K (2006) The U.S. gender pay gap in the 1990s: slowing convergence. Ind Labor Relat Rev 60:45-66

Cain G (1986) The economic analysis of labor market discrimination: a survey. In: Ashenfelter O, Layard PRG (eds) Handbook of labor economics, volume 2. North-Holland, Amsterdam

Devereux P, Hart R (2006) Real-wage cyclicality of job stayers, within-company job movers, and between-company job movers. Ind Labor Relat Rev 60:105-119 
Dustmann C, Glitz A, Vogel T (2010) Employment, wages and the economic cycle: differences between immigrants and natives. Eur Econ Rev 54:1-17

Elsby M, Bart H, Aysegul S (2010) The labor market in the great recession. Brookings Pap Econ Act 41:1-56

Freeman R (1973) Changes in the labor market for black Americans, 1948-72. Brookings Pap Econ Act 6:67-131

Freeman R (1984) Longitudinal analyses of the effects of trade unions. J Labor Econ 2:1-26

Fryer R (2011) Racial inequality in the $21^{\text {st }}$ century: the declining significance of discrimination. In: Ashenfelter O, Card D (eds) Handbook of Labor Economics, Volume 4B. Elsevier, Amsterdam

Hall R (1970) Why is the unemployment rate so high at full employment? Brookings Pap Econ Act 3:369-410

Kay FM, Gorman EH (2012) Developmental practices, organizational culture, and minority representation in organizational leadership: the case of partners in large U.S. law firms. Ann Am Acad Pol Soc Sci 639:91-113

Kuhn P, Shen K (2013) Gender discrimination in job ads: evidence from China. Q J Econ 128:287-336

Marston S (1985) Two views of the geographic distribution of unemployment. Q J Econ 100:57-79

Mulligan C, Rubinstein Y (2008) Selection, investment and women's relative wages over time. Q J Econ 123:1061-1110

O'Neill J (1985) The trend in the male-female wage gap in the United States. J Labor Econ 3:S91-S116

Park S, Shin D (2005) Explaining procyclical male-female wage gaps. Econ Lett 88:231-235

Rosén Å (2003) Search, bargaining and employer discrimination. J Labor Econ 21:807-829

Smith A (1776) The wealth of nations. W. Strahan and T. Cadell, London

Strolovitch, Dara Z (1998) Playing favorites: public attitudes toward race- and gender-targeted anti-discrimination policy. NWSA Journal 10:27-53

doi:10.1186/2193-9004-2-7

Cite this article as: Biddle and Hamermesh: Wage discrimination over the business cycle. IZA Journal of Labor Policy $20132: 7$.

Submit your manuscript to a SpringerOpen ${ }^{\odot}$ journal and benefit from:

- Convenient online submission

Rigorous peer review

- Immediate publication on acceptance

- Open access: articles freely available online

- High visibility within the field

Retaining the copyright to your article

Submit your next manuscript at $\gg$ springeropen.com 